\title{
Neurological Manifestations of Celiac Disease
}

\author{
Ehsan Pishva ${ }^{1}$, Afshin Borhani Haghighi ${ }^{\bowtie}$, Soheil Ashkani-Esfahani ${ }^{3}$, Fereshte Bagheri ${ }^{3}$, Aliasghar Karimi ${ }^{3,4}$, Reza
} Malekzadeh $^{5}$

${ }^{1}$ School for Mental Health and Neuroscience, Maastricht University, Maastricht, Netherlands

${ }^{2}$ Department of Neurology, Medical School, Shiraz University of Medical Sciences, Shiraz, Iran

${ }^{3}$ Student Research Committee, Shiraz University of Medical Sciences, Shiraz, Iran

${ }^{4}$ Student Research Committee, Fasa University of Medical Sciences, Fasa, Iran

${ }^{5}$ Digestive Disease Research Center, Tehran University of Medical Sciences, Tehran, Iran

\begin{abstract}
Celiac disease (CD) is a rare malabsorption syndrome mainly occurring in childhood which is now recognized as the most common food intolerance disease in the world. CD is associated with a wide spectrum of extra intestinal manifestations. Neurological involvements of CD were first attributed to malabsorption due to changes in the mucosal architecture of the small intestine. Neurological manifestations were more frequent in middle-aged adults, but were rare in children. The most common central nervous system manifestations include cerebellar malfunctions, seizures, dementia, multiple sclerosis like presentations, motor neuron diseases, headaches, movement disorders, and neuro-psychiatric presentations. On the other hand, the peripheral nervous system involvement includes different types of peripheral neuropathies and muscular involvements. In this study, we embarked on a short review to go through the neurological presentations and problems of CD.[GMJ. 2013;2(2):60-75]
\end{abstract}

Keywords: Celiac Disease; Nervous system; malabsorption syndrome; Review

\section{Introduction}

Cliac Disease (CD, also called non tropical sprue or gluten-sensitive enteropathy), an autoimmune enteropathy, was first described in 1888 by Samuel and was originally considered a rare malabsorption syndrome mainly occurring in childhood which is now recognized as the most common food intolerance disease in the world. CD is triggered by ingestion of wheat gluten and the related cereal proteins and may arise at any age with a growing proportion of new cases diagnosed in adults, especially in genetically predisposed individuals [1-3]. Recent studies

\section{GMJ}

2013 Galen Medical Journal

Fax: +98 7312227091

PO Box 7461686688

Email:info@gmj.ir have revealed that $\mathrm{CD}$ affects approximately $1 \%$ of the general population across the globe [4]. Almost all the CD patients have a genetic susceptibility characterized by HLA-DQ2 and/or HLADQ8 positivity. Genome-wide association studies during the last 3 years have reported more than a dozen new susceptibility loci for CD [1]. Analysis of eQTL data from these and previously established risk loci sheds light on the genetic pathways underlying this common autoimmune disease [5]. $\mathrm{CD}$ diagnosis requires the positivity of transglutaminase antibody and MARSH III grading at histology. It is still debated that MARSH I or II are overt in CD even in association with

\footnotetext{
Correspondence to:

Prof. Afshin Borhani Haghighi, Department of

Neurology, Medical School, Shiraz University of

Medical Sciences, Shiraz, Iran

Telephone Number: +98917-7029134

Email Address :borhanihaghighi@yahoo.com
} 
positive antibodies. Gluten hypersensitivity requires the positivity of transglutaminase antibody with normal histology or MARSH I and II grading at histology [6]. Small-bowel mucosal morphology was classified according to the Marsh criteria: normal histology (Marsh 0), infiltrative lesion (Marsh I), infiltrative-crypthyperplastic lesions (Marsh II), partial villous atrophy (Marsh IIIA), and subtotal villous atrophy crypt hyperplasia (Marsh IIIB) $[7,8]$.

$\mathrm{CD}$ is associated with a wide spectrum of extra intestinal manifestations [9]. Although CD is one of the most common lifelong inflammatory diseases, most affected individuals remain undiagnosed [1]. The patients with asymptomatic $\mathrm{CD}$ who have no symptoms and respond to gluten withdrawal are often diagnosed through screening programs or in casedetecting strategies for the patients with disorders that are accompanied with a high risk for CD $[10,11]$. Among the affected subjects, only $25 \%$ developed the clinical symptoms. Many patients, especially those presenting in adulthood, have minimal or atypical symptoms, unexpected associations such as epilepsy, and various undefined neurological disorders [2,9]. Gluten intolerance is also another synonym used for $\mathrm{CD}$ to indicate the clinical improvement of the patients subsequent to Gluten Free Diet (GFD) initiation, even when they do not have CD [12-14].

Neurological manifestations of CD have been investigated and reported in a number of studies by many researchers. However, there are a few review studies regarding this aspect of $\mathrm{CD}$ presentations. In the present study we aimed to provide a narrative review on the neurological presentations of CD.

\section{History and Demography}

Carnegie Brown in 1908 reported the first neurological manifestations of $\mathrm{CD}$ in two patients with "peripheral neuritis" [15]. Besides, Elders reported the association between "sprue" and ataxia in 1925 [16]. In 1966, Cook and Smith described 16 patients with different neurological manifestations associated with adult $\mathrm{CD}$, including severe progressive neuropathy, gait ataxia, and limb ataxia. They also reported the first postmortem neuropathological examinations of the patients with neurological involvement of CD showing extensive perivascular inflammatory changes in both central and peripheral nervous systems. A striking feature was the loss of Purkinje cells with atrophy and gliosis of the cerebellum [17]. Neurological involvements of CD were first attributed to malabsorption due to changes in the mucosal architecture of the small intestine[18]. Malabsorption theory has been outmoded as overt malabsorption in CD is rare due to developed diagnostic methods. Studies demonstrated the presence of neurological complications of CD in spite of normal amounts of essential nutritional elements. In 1966, Marks et al. suggested a probable association between inflammatory mechanisms and $\mathrm{CD}$ by demonstrating the similar pattern of enteropathy in both dermatitis herpetiformis, as an inflammatory disease, and CD [19]. On the other hand, Willis et al. also took detailed histories and performed careful clinical examinations in 35 patients with dermatitis herpetiformis and found no evidence for immune mediated neurological damage [20]. Presence of inflammatory cell infiltration in the histopathological findings of the patients with $\mathrm{CD}$ and neurological manifestations led the investigators to think of an autoimmune mechanism [17,21].

\section{Prevalence}

Table 1 shows retro/prospective series of the $\mathrm{CD}$ patients investigated for neurological manifestations. Overall, 334 out of the 1562 patients with $\mathrm{CD}$ had neurological manifes-

Table - 1. Frequency of Neurological Involvement In Celiac Disease

\begin{tabular}{ccccc|}
\hline Author & Year & Country & \multicolumn{2}{c|}{ Neurological involvement (\%) } \\
\hline$[17]$ & 1966 & UK & $16 / 266$ & $6 \%$ \\
{$[22]$} & 1971 & Ireland & $42 / 15$ & $35.7 \%$ \\
{$[23]$} & 1999 & Finland & $10 / 144$ & $7 \%$ \\
{$[24]$} & 2002 & UK & $189 / 620$ & $30 \%$ \\
{$[25]$} & 2002 & Italy & $13 / 160$ & $8 \%$ \\
{$[26]$} & 2004 & Israel & $18 / 148$ & $12 \%$ \\
{$[27]$} & 2004 & Israel & $57 / 111$ & $51.4 \%$ \\
{$[28]$} & 2008 & USA & $16 / 71$ & $22.5 \%$ \\
\hline
\end{tabular}


tations. The Frequency of neurologic system involvement in $\mathrm{CD}$ in these series reveals high degree of variation. This variation may not only be due to the environmental and ethnic factors, but also related to variable definitions and methodologies in different studies.

Sex: Hadjivassilliou and colleagues reported female to male ratio of the patients with neurological manifestations of $\mathrm{CD}$ as approximately 1:1 in one series [29].

Age: Neurological manifestations were more frequent in middle-aged adults, but rare in children $[27,30,31]$. In addition, the mean age at the onset of neurological manifestations was 48 years in one series [29].

\section{Pathology}

The pathological findings of CNS involvement in CD include lymphocytic infiltration (mainly T cell), especially in the spinal cord, hypothalamus, cerebellum, and brainstem [17,32], astrocytic gliosis, vacuolization of the neuropil of the cerebellar white matter [32], cerebellar purkinje cell loss [17,21,32,33], and demyelination in the posterior, lateral, and anterior cortico-spinal tracts in the cord [17,21]. Shams et al. reported extensive infiltration by medium sized cells with pleomorphic nuclei and prominent nucleoli in the cerebellar cortex and white matter which stained positively for CD45, CD3, and TIA-1 (cytotoxic granule marker) [34]. Moreover, Hadjivassiliou et al. found widespread Ig A deposition around the vessels in the brain of the patient with gluten ataxia. The deposition was most pronounced in the cerebellum, pons, and medulla [35]. In two CD patients with headache, autopsy results showed evidence of vasculitis [36].

The pathological findings in sural nerve biopsy of the patients with CD and neuropathy revealed changes of chronic axonopathy [37,38], wallerian degeneration, and degeneration-regeneration of nerve fibers [39].

\section{Pathogenesis}

Etiopathogenesis of the neurological manifestations of CD remains to be elucidated. There are cohorts of studies advocating the theory that gluten can affect cell function in cell culture systems, apparently in the absence of the immune system involvement. Gluten has shown this effect by inducing agglutination of K562(S) myelogenous leukemia cells, leading to actin rearrangement, and finally triggering apoptosis in Caco-2 cells [40]. Meanwhile, the presence of inflammatory reactions in the neural tissue of the postmortem pathological examination of the patients with CD and neurological complications led the investigators to think about an immunological mechanism, too $[17,21,32]$. In general, two speculated immunological mechanisms may explain the association between gluten sensitivity and neurological manifestations: Antigen molecular mimicry and Intermolecular help.

\section{Antigen molecular mimicry (Antibody cross -reactivity): The speculated mecha- nisms of molecular mimicry in the patients with gluten sensitivity are:}

1. Cross reactivity between gliadin species and gangliosides: Antigliadin antibodies may cross-react with Purkinje cells. Gliadin proteins and cerebellar Purkinje cells may share common epitopes. Such common epitopes have also been demonstrated to exist between gliadin proteins and enterocytes [41]. Up to $65 \%$ of the patients with celiac neuropathy had antibodies targeting one or more gangliosides $[37,38]$. It has been shown that some gluten species are glycosylates containing epitopes probably similar to ganglioside carbohydrates [42]. This may justify the induction of the antibody cross-reactivity. Moreover, in experimental studies, serum of the neurologically symptom-free CD patients demonstrated cross-reactivity with epitopes on Purkinje cells of both human and rat cerebellum [41]. Interestingly, elimination of antigliadin antibodies (AGA) from serum of the patients with $\mathrm{CD}$ and ataxia did not ameliorate the reaction to the Purkinje cells. This might have led the investigators to assume the presence of other antibodies against Purkinje cells in the patients with $C D$ and cerebellar manifestations. Anti-ganglio 
1. side antibodies may be the example. Alaedini et al. proposed synapsin I, a cytosolic phosphoprotein, as the target of cross reactivity with anti-gliadin antibodies in both central and peripheral nervous systems [43].

2. Predisposition to infection with organisms, such as Campylobacter jejuni or Haemophilus influenzae which have lipopolysaccharides similar to CNS or PNS gangliosides. This mode has analogies to the hypothesized pathogenesis of Guillain-Barre' syndrome [44].

3. Another unknown mechanism: Investigations are still needed in order to approve this hypothesis and since there may be other unknown mechanisms involved in or facilitating the antibody cross-reactivity.

\section{Intermolecular help theory}

Gliadin molecules are deamidated by tissue transglutaminase (tTG). It has been speculated that tTG-specific B cells engulf the gliadin-tTG complex and present the gliadin portion to gliadin-sensitized T cells. The ensuing gliadin-reactive $\mathrm{T}$ cell helper could induce the ganglioside- specific B cells and produce anti-ganglioside antibodies in the absence of ganglioside-specific T cells [45].

\section{Clinical manifestations}

Neurological involvement in gluten sensitivity can be categorized into central and peripheral nervous system manifestations. The most common central nervous system manifestations include cerebellar syndromes, seizures, and dementias. Multiple sclerosis like presentations, motor neuron diseases, headaches, movement disorders, and neuro-psychiatric presentations, have been reported, as well. On the other hand, the peripheral nervous system involvement includes different types of peripheral neuropathies and muscular involvement. Mixed neurological syndromes are also prevalent; $45-68 \%$ of the patients with gluten sensitivity ataxia revealed electrophysiological evidences of neuropathy, too [29,32].

\section{Central nervous system involvement}

\section{1- Ataxia}

Gait and limb ataxia, myoclonus, occulomotor abnormalities, and dyarthria are the various cerebellar manifestations of CD. In a study by Hadjivassiliou et al., gait ataxia, lower limb ataxia, ocular signs, upper limb ataxia, and dysarthria were seen in $100 \%, 90 \%, 84 \%$, $75 \%$, and $66 \%$ of the patients, respectively [46]. Deconinck et al. reported a single case with opsoclonus- myoclonus associated with $\mathrm{CD}$ [47]. The frequencies of $\mathrm{CD}$ and gluten sensitivity in patients with ataxia of unknown origin have been reported between 1.9-15\% and $12-47 \%$, respectively $[46,48,49]$. In other studies, $13 \%$ of the patients with hereditary cerebellar ataxias and $23 \%$ of those with spinocerebellar ataxia type 2 had positive AGA [49-52]. On the contrary, some other studies showed no association between $\mathrm{CD}$ and idiopathic cerebellar ataxia [53-55]. Table 2 shows reports regarding the association between $\mathrm{CD}$ and epilepsy ataxia

\section{2- Seizures}

Several reports are available regarding the association between CD and epilepsy (Table 3 ). These studies did not separate drug-naïve epileptic patients from those who were on anti-epileptic drugs at time of study. As several anti-epileptic drugs induce the immune system and auto-antibodies are frequently seen in epileptic patients, clinical significance of this finding should be considered with caution. Gobbi et al. considered constellation of $\mathrm{CD}$, epilepsy, and cerebral calcifications as a particular entity, CEC syndrome [56]. Efficacy of Gluten restriction seems to be inversely related to the duration of epilepsy and the young age of the patients. As cerebral calcification was not seen in the patients of Cronin et al. with epilepsy and CD, CEC syndrome may be a geographically based association rather than a distinct entity [57].

\section{3- Multiple Sclerosis}

In all [58-61] but one [62] case-control studies, no association was found between $C D$ and gluten sensitivity, and MS. There are also 
Table 2. Available Reports Regarding The Association Between Cd And Epilepsy Ataxia

\begin{tabular}{|c|c|c|c|c|c|c|c|}
\hline Study & Year & Country & Study Population & $\begin{array}{l}\text { Study } \\
\text { Type }\end{array}$ & Investigation & $\begin{array}{c}\text { Major } \\
\text { Findings }\end{array}$ & $\begin{array}{c}\text { Major } \\
\text { Conclusion }\end{array}$ \\
\hline $\begin{array}{l}\text { Hadjivassiliou } \\
\text { et al. }\end{array}$ & 1996 & UK & $\begin{array}{l}25 \text { patients with } \\
\text { Sporadic Ataxia }\end{array}$ & Descriptive & AGA, Biopsy & $\begin{array}{l}\text { CD: in } 16 \% \text { of } \\
\text { patients }\end{array}$ & $\begin{array}{l}\text { gluten sensitivity } \\
\text { is common } \\
\text { in patients } \\
\text { with ataxia of } \\
\text { unknown cause }\end{array}$ \\
\hline $\begin{array}{l}\text { Pellecchia } \\
\text { et al }\end{array}$ & 1999 & Italy & $\begin{array}{l}24 \text { patients with } \\
\text { idiopathic ataxia } \\
23 \text { patients with } \\
\text { hereditary ataxia }\end{array}$ & Descriptive & $\begin{array}{l}\text { AEmA, AGA, } \\
\text { Biopsy }\end{array}$ & $\begin{array}{l}\text { CD: in } 12.5 \% \\
\text { of patients } \\
\text { with idiopathic } \\
\text { ataxia } \\
\text { And } 0 \% \text { of } \\
\text { patients with } \\
\text { hereditary } \\
\text { ataxia }\end{array}$ & $\begin{array}{l}\text { Association } \\
\text { between CD and } \\
\text { atxia }\end{array}$ \\
\hline $\begin{array}{l}\text { Combarros } \\
\text { et al }\end{array}$ & 2000 & Spain & $\begin{array}{l}32 \text { patients with } \\
\text { idiopathic ataxia }\end{array}$ & Descriptive & $\begin{array}{l}\text { AGA,A EmA } \\
\text { ARA, AtTGA }\end{array}$ & $\begin{array}{l}\mathrm{CD}: \text { in } 0 \% \text { of } \\
\text { patients }\end{array}$ & $\begin{array}{l}\text { No association } \\
\text { between } C D \text { and } \\
\text { atxia }\end{array}$ \\
\hline Bushara et al & 2001 & USA & $\begin{array}{l}26 \text { patients with } \\
\text { sporadic ataxia } \\
24 \text { patients with } \\
\text { Hereditary ataxia }\end{array}$ & Descriptive & $\begin{array}{l}\text { AGA,AEmA, } \\
\text { ARA, AtTGA, } \\
\text { Biopsy }\end{array}$ & $\begin{array}{l}\text { +AGA: } 27 \% \text { of } \\
\text { patients with } \\
\text { sporadic ataxia, } \\
37 \% \text { of patients } \\
\text { of hereditary } \\
\text { cerebellar } \\
\text { ataxia, } \\
\text { Definite CD:? }\end{array}$ & $\begin{array}{l}\text { Association } \\
\text { between CD and } \\
\text { ataxia }\end{array}$ \\
\hline Burk et al. & 2001 & Germany & $\begin{array}{l}104 \text { patients with } \\
\text { sporadic ataxia }\end{array}$ & Descriptive & $\begin{array}{l}\text { AGA, AEmA, } \\
\text { HLA, Biopsy }\end{array}$ & $\begin{array}{l}\text { GS: } 10.6 \% \text { of } \\
\text { patients } \\
\text { CD: } 1.9 \% \text { of } \\
\text { patients }\end{array}$ & $\begin{array}{l}\text { Association } \\
\text { between } C D \text { and } \\
\text { ataxia }\end{array}$ \\
\hline $\begin{array}{l}\text { Luostarinen } \\
\text { et al }\end{array}$ & 2001 & Finland & $\begin{array}{l}44 \text { patients with } \\
\text { idiopathic ataxia }\end{array}$ & Descriptive & $\begin{array}{l}\text { AGA,AEmA, } \\
\text { AtTGA, } \\
\text { Biopsy }\end{array}$ & $\begin{array}{l}\mathrm{CD}: 16.7 \% \text { of } \\
\text { patients }\end{array}$ & $\begin{array}{l}\text { Association } \\
\text { between CD and } \\
\text { ataxia }\end{array}$ \\
\hline $\begin{array}{l}\text { Hadjivassiliou } \\
\text { et al. }\end{array}$ & 2003 & UK & $\begin{array}{l}59 \text { patients } \\
\text { with familial } \\
\text { spinocerebellar } \\
\text { ataxia } \\
176 \text { patients with } \\
\text { sporadic idiopathic } \\
\text { ataxia } \\
33 \text { patients with } \\
\text { cerebellar variant } \\
\text { of multiple system } \\
\text { atrophy } \\
1200 \text { control }\end{array}$ & $\begin{array}{l}\text { Case- } \\
\text { control }\end{array}$ & AGA & $\begin{array}{l}\text { GS: } 14 \% \\
\text { familial } \\
\text { spinocerebellar } \\
\text { ataxia } \\
39 \% \text { of } \\
\text { sporadic } \\
\text { idiopathic } \\
\text { ataxia } \\
15 \% \text { cerebellar } \\
\text { variant of } \\
\text { multiple system } \\
\text { atrophy } \\
12 \% \text { control } \\
\text { CD in } 24 \% \text { of } \\
\text { "gluten ataxia" }\end{array}$ & $\begin{array}{l}\text { Association } \\
\text { between } C D \text { and } \\
\text { ataxia }\end{array}$ \\
\hline
\end{tabular}

some case reports on the association between Neuromyelitis optica and CD $[63,64]$.

\section{4- Headache}

In one study on pediatric age group [65] and one study on adults [66], CD was significantly more prevalent in the patients with migraine headaches in comparison to the healthy con- trols. Headac0he was also more prevalent in the $\mathrm{CD}$ patients compared to the healthy controls [67]. Besides, migraine and tension-type headaches were the most common types of headaches in the patients with CD [68]. Yet, adherence to GFD was efficacious in decreasing the frequency of headaches in some CD populations $[36,67,69,70]$. 
Table-3. Available Reports Regarding The Association Between Cd And Epilepsy

\begin{tabular}{|c|c|c|c|c|c|c|c|}
\hline Study & Year & Country & $\begin{array}{c}\text { Study } \\
\text { Population }\end{array}$ & $\begin{array}{l}\text { Study } \\
\text { Type }\end{array}$ & Investigation & $\begin{array}{c}\text { Major } \\
\text { Findings }\end{array}$ & $\begin{array}{c}\text { Major } \\
\text { conclusion }\end{array}$ \\
\hline Chapman & 1978 & USA & $\begin{array}{l}165 \text { CD patients } \\
165 \text { controls }\end{array}$ & Case-control & Questionnaire & $\begin{array}{l}\text { Epilepsy: } 5.5 \% \\
\text { in CD patients, } \\
0 \% \text { in controls }\end{array}$ & $\begin{array}{l}\text { Increased prevalence } \\
\text { of epilepsy in coeliac } \\
\text { disease }\end{array}$ \\
\hline Fois et al. & 1994 & Italy & $\begin{array}{l}783 \text { patients with } \\
\text { seizure disorders }\end{array}$ & Descriptive & $\begin{array}{l}\text { AGA, AEmA, } \\
\text { biopsy }\end{array}$ & $\begin{array}{l}\mathrm{CD}: 2.3 \% \text { in } \\
\text { patients }\end{array}$ & \\
\hline Cronin et al. & 1998 & Ireland & $\begin{array}{l}177 \text { with seizure } \\
\text { disorders } \\
488 \text { controls }\end{array}$ & Case-control & AEmA, biopsy & $\begin{array}{l}\text { GS: } 2.3 \% \text { in } \\
\text { patients } \\
0.4 \% \text { in controls }\end{array}$ & $\begin{array}{l}\text { Increased prevalence } \\
\text { of gluten sensitivity } \\
\text { in patients with } \\
\text { seizure }\end{array}$ \\
\hline Labate et al. & 2001 & Italy & $\begin{array}{l}72 \text { patients with } \\
\text { childhood partial } \\
\text { epilepsy }\end{array}$ & Descriptive & $\begin{array}{l}\text { AGA, AEmA, } \\
\text { biopsy }\end{array}$ & $\begin{array}{l}\mathrm{CD}: 2.7 \% \text { of } \\
\text { patients }\end{array}$ & $\begin{array}{l}\text { CD screening } \\
\text { should be performed } \\
\text { routinely only } \\
\text { in patients with } \\
\text { childhood partial } \\
\text { epilepsy with occipital } \\
\text { paroxysms }\end{array}$ \\
\hline $\begin{array}{l}\text { Luostarinen } \\
\text { et al. }\end{array}$ & 2001 & Finland & $\begin{array}{l}199 \text { patients } \\
\text { with epilepsy } \\
\text { of unknown } \\
\text { aetiology }\end{array}$ & Descriptive & $\begin{array}{l}\text { serological } \\
\text { screening, } \\
\text { biopsy }\end{array}$ & $\begin{array}{l}\text { CD: } 2.5 \% \text { in } \\
\text { patients }\end{array}$ & $\begin{array}{l}\text { Association between } \\
\mathrm{CD} \text {, epilepsy and } \\
\text { brain } \\
\text { atrophy }\end{array}$ \\
\hline Essid et al & 2003 & Tunis & $\begin{array}{l}49 \text { patients with } \\
\text { epilepsy }\end{array}$ & Descriptive & Biopsy & $\begin{array}{l}\mathrm{CD}: 8.1 \% \text { in } \\
\text { patients }\end{array}$ & \\
\hline Pratesi et al & 2003 & Brazil & $\begin{array}{l}255 \text { patients with } \\
\text { epilepsy } \\
4405 \text { controls }\end{array}$ & Case-control & EmA, biopsy & $\begin{array}{l}\mathrm{CD}: 0.8 \text { in } \\
\text { patients } \\
0.3 \% \text { in controls }\end{array}$ & $\begin{array}{l}\text { Not statistically } \\
\text { significant increased } \\
\text { prevalence of } C D \text { in } \\
\text { epileptic patients }\end{array}$ \\
\hline Pengiran et al & 2004 & UK & $801 \mathrm{CD}$ patients & Descriptive & $\begin{array}{l}\text { Interview, chart } \\
\text { review }\end{array}$ & $\begin{array}{l}\text { History of } \\
\text { seizure: } \\
2.6 \% \text { in } \mathrm{CD} \\
\text { patients; active } \\
\text { epilepsy: } 1.1 \%\end{array}$ & $\begin{array}{l}\text { No association } \\
\text { between CD and } \\
\text { active epilepsy }\end{array}$ \\
\hline Rauna J et & 2005 & Finland & $\begin{array}{l}968 \text { patients with } \\
\text { epilepsy } \\
\text { 584Control }\end{array}$ & Case-control & $\begin{array}{l}\text { AGA, AEmA, } \\
\text { AtTGA }\end{array}$ & $\begin{array}{l}\text { Only AGA } \\
\text { IgA type was } \\
\text { more prevalent } \\
\text { in patients } \\
\text { with primary } \\
\text { generalized }\end{array}$ & \\
\hline Dalgic et al & 2006 & Turkey & $\begin{array}{l}70 \text { pediatric } \\
\text { patients with } \\
\text { epilepsy } \\
103 \text { Controls }\end{array}$ & Case-control & $\begin{array}{l}\text { AtTGA, } \\
\text { Biopsy }\end{array}$ & $\begin{array}{l}\mathrm{CD}: 1.7 \% \text { in } \\
\text { patients } \\
0 \% \text { in controls }\end{array}$ & $\begin{array}{l}\text { Association between } \\
\mathrm{CD} \text { and epilepsy in } \\
\text { children }\end{array}$ \\
\hline Antigoni etal & 2007 & Greece & $\begin{array}{l}255 \text { pediatric } \\
\text { patients with } \\
\text { epilepsy } \\
280 \text { controls }\end{array}$ & Case-control & $\begin{array}{l}\text { AtTGA, AGA, } \\
\text { ARA,AEmA, } \\
\text { biopsy }\end{array}$ & $\begin{array}{l}\text { GS: } 1.9 \% \text { in } \\
\text { patients } \\
0 \% \text { in controls }\end{array}$ & $\begin{array}{l}\text { Association between } \\
\mathrm{CD} \text { and epilepsy in } \\
\text { children }\end{array}$ \\
\hline Emami et al & 2008 & Iran & $\begin{array}{l}108 \text { epileptic } \\
\text { patients }\end{array}$ & Descriptive & $\begin{array}{l}\text { AtTGA, } \\
\text { Biopsy }\end{array}$ & $\begin{array}{l}\mathrm{CD}: 2.8 \% \text { of } \\
\text { patients }\end{array}$ & $\begin{array}{l}\text { Association between } \\
\mathrm{CD} \text { and epilepsy }\end{array}$ \\
\hline Giordano et al & 2009 & Italy & $\begin{array}{l}272 \text { pediatric } \\
\text { patients with } \\
\text { epilepsy; } \\
300 \text { controls }\end{array}$ & Case-control & $\begin{array}{l}\text { AGA, AEmA, } \\
\text { AtTGA }\end{array}$ & $\begin{array}{l}\text { GS: } 2.6 \% \text { in } \\
\text { patients In } \\
\text { controls }\end{array}$ & $\begin{array}{l}\text { No association } \\
\text { between } C D \text { and } \\
\text { epilepsy in children }\end{array}$ \\
\hline Peltola et al & 2009 & Finland & $\begin{array}{l}48 \text { patients with } \\
\text { therapy-resistant, } \\
\text { localisation- } \\
\text { related epilepsy }\end{array}$ & Descriptive & $\begin{array}{l}\text { AGA, AEmA, } \\
\text { AtTGA, HLA }\end{array}$ & $\begin{array}{l}\text { GS: } 14.6 \% \text { of } \\
\text { patients }\end{array}$ & $\begin{array}{l}\text { Association between } \\
\text { gluten sensitivity, } \\
\text { temporal lobe epilepsy } \\
\text { and hippocampal } \\
\text { sclerosis }\end{array}$ \\
\hline Ertekin et al & 2010 & Turkey & $\begin{array}{l}77 \text { pediatric } \\
\text { patients with } \\
\text { epilepsy }\end{array}$ & Descriptive & AtTGA & $\begin{array}{l}\text { GS: } 15.6 \% \text { of } \\
\text { patients }\end{array}$ & \\
\hline
\end{tabular}


Hadjivassiliou et al. considered the term "gluten encephalopathy" for the patients with gluten sensitivity, migraine-like headache, possible focal neurological deficits, and vascular type white matter Magnetic Resonance Imaging (MRI) abnormalities [36].

\section{5- Dementia}

There are a few case series about the association between dementia and $\mathrm{CD}[71,72]$. In one study, the frequency of CD in Alzheimer's patients was not higher than the controls [73]. Furthermore, in another study, cognitive impairment was not found in CD patients [74]. Of course, both studies had been conducted on small sample sizes.

\section{6- Neuro-Psychiatric Manifestations}

Psychological reactions to a chronic disabling illness, such as $\mathrm{CD}$, may interfere with the diagnosis of neurological complications. For instance, $19-35 \%$ of the patients with CD had a positive history of psychiatric diseases $[75,76]$. Although some studies revealed no associations between $\mathrm{CD}$ and schizophrenia in adults and autism in children [77-79], several authors have declared that an association may exist between $\mathrm{CD}$ and autism and between $\mathrm{CD}$ or gluten sensitivity and psychiatric disorders [14]. A few studies have also mentioned the efficacy of dietary intervention in autism [8082].

\section{7- Movement Disorders}

Palatal myoclonus [21], opsoclonus-myoclonus syndrome [47], dystonia paralysis [83], Rhabdomyolysis [84], and choreathetosis $[85,86]$ were reported in the patients with $\mathrm{CD}$.

\section{8- Hearing loss}

Increased frequency of sensori-neural hearing loss in the patients with $\mathrm{CD}$ compared to the healthy controls was reported in two studies $[87,88]$.

\section{9- Stroke}

There were case reports of stroke in the children and young adults with diagnosis of $C D$ $[89,90]$. However, as the majority of these patients had other contributing factors, a cause and effect relationship between $\mathrm{CD}$ and stroke is a matter of debate.

\section{0- Spinal cord disorders}

In addition to the above mentioned case reports of neuro-myelitis optica with gluten sensitivity, isolated myelopathy has also been reported [91]. Goodman et al. reported that myeloneuropathy secondary to Copper deficiency occulted $\mathrm{CD}$ in the patient with progressive gait unsteadiness [92]. In addition, Hadjivassiliou et al. reported gluten sensitivity in $6 / 7$ and $C D$ in $1 / 7$ of the patients with Stiff-Person syndrome, a syndrome which is a rare neurologic disorder with autoimmune characteristics. It is described by progressive, severe muscle rigidity or stiffness most importantly involving the spine and lower extremities [52,93].

\section{Peripheral Nervous System Involvement}

\section{1- Neuropathies}

Peripheral nervous system manifestations in CD include Guillain-Barre syndrome, predominately sensory polyneuropathy, mononeuritis multiplex, and autonomic neuropathy (Table 4) $[38,94,95]$. Of course, it should be mentioned that small fibers are more involved [95]. Celiac neuropathy commonly presents with paresthesia, dysesthesia, and areflexia. However, weakness and muscle wasting is less frequent.

In a population-based Swedish study, CD was significantly associated with only polyneuropathy, but not with other neuro-inflammatory or neuro-degenerative disorders [96]. The frequency of neuropathy in the patients with $\mathrm{CD}$ has been reported to be between 2.5$23 \%$. Neuropathy is one of the most common neurological manifestations of gluten sensitivity $[39,48]$. The largest prospective study looking for the prevalence of gluten neuropathy showed that among the patients with idiopathic axonal peripheral neuropathy, $34 \%$ had circulating antigliadin antibodies. This value was reported as $12 \%$ in the healthy population [97]. Meanwhile, some other studies revealed no increased frequency of gluten sensitivity in the patients with idiopathic neuropathy [54]. 
Table-4. Available Reports Regarding The Association Between Cd And Neuropathy

\begin{tabular}{|c|c|c|c|c|c|c|c|}
\hline Study & Year & Country & $\begin{array}{c}\text { Study } \\
\text { Population }\end{array}$ & $\begin{array}{l}\text { Study } \\
\text { Type }\end{array}$ & Investigation & Major Findings & $\begin{array}{c}\text { Major } \\
\text { Conclusion }\end{array}$ \\
\hline $\begin{array}{l}\text { Hadjivassiliou } \\
\text { et al. }\end{array}$ & 1996 & UK & $\begin{array}{l}25 \text { patients } \\
\text { with } \\
\text { sporadic } P N\end{array}$ & Descriptive & AGA, Biopsy & $\mathrm{CD}:$ in $8 \%$ of ptients & $\begin{array}{l}\text { gluten } \\
\text { sensitivity is } \\
\text { common in } \\
\text { patients with } \\
\text { neuropathy of } \\
\text { unknown cause }\end{array}$ \\
\hline $\begin{array}{l}\text { Luostarinen } \\
\text { et al }\end{array}$ & 2003 & Finland & $\begin{array}{l}26 \mathrm{CD} \\
\text { patients } \\
23 \text { controls }\end{array}$ & Case-control & $\begin{array}{l}\text { Electrodiagnostic } \\
\text { studies }\end{array}$ & $\begin{array}{l}\text { chronic axonal neuropathy } \\
: 23.1 \% \text { in patients } \\
4.3 \% \text { in controls }\end{array}$ & $\begin{array}{l}\text { increased } \\
\text { occurrence } \\
\text { of axonal } \\
\text { neuropathy was } \\
\text { observed in well } \\
\text { treated celiac } \\
\text { disease }\end{array}$ \\
\hline Chin et al & 2003 & USA & $\begin{array}{l}20 \mathrm{CD} \\
\text { patients with } \\
\text { neuropathy }\end{array}$ & Descriptive & $\begin{array}{l}\text { Electrodiagnostic } \\
\text { studies, sural } \\
\text { nerve biopsy }\end{array}$ & $\begin{array}{l}\text { Sural biopsy in three } \\
\text { patients: mild to severe } \\
\text { axonopathy. } \\
\text { antiganglioside antibodies } \\
\text { in } 65 \% \text { of patients }\end{array}$ & $\begin{array}{l}\text { Association } \\
\text { between CD } \\
\text { and sensory } \\
\text { neuropathy }\end{array}$ \\
\hline $\begin{array}{l}\text { Brannagan } \\
\text { et al }\end{array}$ & 2005 & USA & $\begin{array}{l}8 \mathrm{CD} \\
\text { patients with } \\
\text { neuropathy }\end{array}$ & Descriptive & $\begin{array}{l}\text { Electrodiagnostic } \\
\text { studies, epidermal } \\
\text { nerve fiber (ENF) } \\
\text { density }\end{array}$ & $\begin{array}{l}\text { Normal NCV: } 7 \text { patients } \\
\text { Reduced ENF: } 5 \text { patients }\end{array}$ & $\begin{array}{l}\text { sensory } \\
\text { ganglionopathy } \\
\text { or an immune- } \\
\text { mediated } \\
\text { neuropathy in } \\
\text { CD }\end{array}$ \\
\hline Lock et al & 2005 & UK & $\begin{array}{l}32 \text { patients } \\
\text { with } \mathrm{PN}\end{array}$ & Descriptive & AtTGA, HLA & GS: $0 \%$ & $\begin{array}{l}\text { No association } \\
\text { between } C D \text { and } \\
\text { neuropathy }\end{array}$ \\
\hline $\begin{array}{l}\text { Gibbons and } \\
\text { Freeman }\end{array}$ & 2005 & USA & $\begin{array}{l}164 \text { patients } \\
\text { with } \\
\text { suspected } \\
\text { autonomic } \\
\text { dysfunction }\end{array}$ & Descriptive & AGA, Biopsy & CD: $2.4 \%$ of patients & \\
\hline Tursi et al. & 2006 & Italy & $\begin{array}{l}32 \mathrm{CD} \\
\text { patients }\end{array}$ & Descriptive & $\begin{array}{l}\text { Electrodiagnostic } \\
\text { studies, } \\
\text { Antineuronal } \\
\text { antibody }\end{array}$ & $\begin{array}{l}\text { peripheral neuropathy: } 12 \\
\text { autonomicdysfunction: } 17 \text {, } \\
\text { or both:3 patients pts }\end{array}$ & \\
\hline Mata et al & 2006 & Italy & $\begin{array}{l}220 \text { patients } \\
\text { with PN } \\
110 \text { patients } \\
\text { with MND }\end{array}$ & Descriptive & $\begin{array}{l}\text { AtTGA, nti- } \\
\text { glycolipid } \\
\text { antibodies }\end{array}$ & $\begin{array}{l}\mathrm{GS}: 2.7 \% \text { in } \mathrm{PN}, \\
0.9 \% \text { in } \mathrm{MND}\end{array}$ & $\begin{array}{l}\text { No increased } \\
\text { risk of celiac } \\
\text { disease }\end{array}$ \\
\hline
\end{tabular}

PN: Peripheral neuropathy, MND: Motor Neuron Disease

\section{2- Myopathy}

Polymyositis [98-100], dermatomyositis [101], and inclusion body myositis [99] were reported to be accompanied with $\mathrm{CD}$. Concomitant neuropathy and myopathy may be present, as well $[99,102]$. Treatment with immunosuppressive drugs and GFD was reported to be efficacious in this regard [99].

The role of gluten sensitivity in the patients with idiopathic neurological disorder

Some studies reported an elevated titer of Antigiladin antibody in the absence of intestinal involvement in a series of patients with neurological dysfunction of unknown cause [103]. Pellechia et al. revealed patients with $\mathrm{CD}$ who presented with idiopathic ataxia before any GI manifestation [104]. In one study, some patients with ataxia and elevated antigliadin antibodies responded to GFD [46].

The importance of undiagnosed gluten sensitivity in the patients with neurological disease of unknown cause is a matter of debate. Some researchers recommended IgG AGA as a part of the routine batteries for all the patients with neurological dysfunction of obscure etiology. On the other hand, other investigators decisively criticized this approach.

In the study by Hadjivassiliou et al., positive titers of antigliadin antibodies were more frequent in a heterogeneous group of patients 
with neurological disease of unknown cause in comparison to the control group (The difference in proportion: $0.49,95 \%$ CI: $0.35-$ $0.63)$. CD was found in $35 \%$ of the duodenal biopsies conducted in this sero-positve group [105]. Moreover, an epidemiological study of the prevalence of gluten ataxia suggested that it may account for up to $40 \%$ of the patients with sporadic idiopathic ataxia [46].

Conventional MRI showed cerebellar atrophy and white matter lesions in the patients with "gluten ataxia" [46]. MR spectroscopy patterns were also different between these patients and the control group [46]. That study also reported the presence of oligoclonal bands in up to $50 \%$ of the patients with gluten ataxia.

Gluten ataxia is the most common single cause of cerebellar ataxia among the patients with supposed idiopathic sporadic ataxia [46]. Recently, researchers found a novel transglutaminase, TG6, which was analog to TG2 and TG3 and was predominantly expressed in the CNS. Neurological presentation of gluten sensitivity in the absence of intestinal pathology can be justified by the role of this enzyme [106]. This team has also some genetic evidences for their speculation; $30 \%$ of general population, $90 \%$ of the patients with $\mathrm{CD}$, and $70 \%$ of the patients with neurological disease and gluten sensitivity had HLADQ2 [29]. However, $20 \%$ of the patients with neurological disease and gluten sensitivity and none of the patients with gastrointestinal $\mathrm{CD}$ had and HLA DQ1 [106].

This may propose a genetic difference between the patients with neurological presentation and those with gastrointestinal presentation within the range of gluten sensitivity [29]. These findings led the "Shefield team" to consider "gluten sensitivity" as a heightened immunological responsiveness to ingested gluten in genetically predisposed individuals with or without intestinal pathology. Gluten ataxia forms a part of a spectrum of disorders associated with gluten sensitivity, including CD (gluten sensitive enteropathy) and dermatitis herpetiformis (gluten sensitive dermatopathy). Nonetheless, some investigators completely disagree with "Shefield School". In one study, neither the patients with idio- pathic ataxia nor the patients with idiopathic neuropathy showed tTG Ab positively. Thus, they considered a reasonable doubt about the neurological status of "gluten ataxia" as a distinct disease entity [54]. In another study, high antigliadin antibody titers were found in $44 \%$ of the patients with Huntington's disease. This finding speculated that antigliadin antibodies in neurodegenerative diseases might be an epiphenomenon [107].

\section{Diagnosis}

Diagnosis is not troublesome when a relevant neurological syndrome occurs in a known case of CD. Diagnostic dilemma mostly appears in the patients who present with neurological problems and incomplete profile of CD or when history taking or physical examinations are not adequate and gluten sensitivity is neglected. MRI is by far the most beneficial imaging study for routine evaluation of neurological manifestations of CD.

\section{MRI}

Cerebellar atrophy and discrete white matter lesions were reported in the patients with $\mathrm{CD}$ $[108,109]$.

\section{CSF}

CSF study of the patients with CD may reveal antigliadin antibodies [110].

\section{Treatment}

\section{Gluten Free Diet}

GFD is the milestone of treatment in serologically and histologically confirmed CD and neurological complications. To the best of our knowledge, no well controlled and prospective studies have been conducted to clarify the effects of GFD on idiopathic neurological disorders suspected to gluten sensitivity. The results of studies (mainly case reports) were also contradictive. Some studies $[46,104]$ were in favor, while others $[110,111]$ were against the therapeutic effects of GFD on the patients with ataxia suspected to gluten sensitivity. There were also contradictive results about administration of GFD to gluten neuropathy. Chin et al. did not find any objective improvement 
with GFD [38], while Hadjivassiliou et al. found subjective improvement with GFD in the patients with idiopathic sensori-motor axonal neuropathy and circulating antigliadin antibodies [112]. There are some case reports on the response to GFD in the patients with epilepsy and cerebellar calcification [113115]. Indeed, the beneficial effects of the diet have been reported as better seizure control and a decrease in antiepileptic drugs, but not complete remission of seizures [116]. There are also some reports on the positive effects of GFD on migraine headaches [36,66], neuropsychological problems $[72,117,118]$, myopathy [30,119], and ALS associated with gluten enteropathy [118]. The effects of a GFD on these patients range from reversal of the dysfunction, stabilization of the illness, and even making little or no difference. Thus, it can be concluded that there is a therapeutic window of opportunity in which commencement of a GFD is helpful. It is very important to monitor the anti-gluten antibodies to know whether the lack of response relates to the lack of compliance or not. Antibody titers may remain high even 6-12 months after starting GFD. Duration of sustained GFD may also affect the response [52]. Ward et al. reported a 47 year old man with spinocerebellar degeneration associated with $\mathrm{CD}$ whose neurologic disorder initially deteriorated in spite of GFD, but stabilized after 4 months [120].

\section{Immunomodulatory treatments}

Administration of Intravenous Immunoglobulin (IVIG) or immunosuppressive drugs has been recommended in the patients with $\mathrm{CD}$ and neurological complications who revealed progression despite gluten free regimen. The therapeutic effects were contradictive, though. However, Souayah et al. [121] and Nanri et al. [122] found improvement with IVIG in three patients with biopsy-proven or antibody positive gluten sensitivity who developed cerebellar ataxia and /or neuropathic pain despite strict adherence to a GFD [121]. In another study by Nanri et al. and the study by Chin et al., the results were futile on celiac neuropathy $[38,123]$. Ait Ben Haddou and his colleagues reported a 41-year-old woman followed up for CD resistant to GFD who de- veloped rapidly spastic paraparesis, cerebellar syndrome, horizontal diplopia, and decline of visual acuity. The diagnosis of neurological complications of $\mathrm{CD}$ was established and the patient was treated with methylprednisolone followed by oral prednisone. For 9 years, the patient's neurological signs were worsening at $15 \mathrm{mg}$ per day; however, the clinical status improved by increasing the dose to $30 \mathrm{mg}$. The positive response to corticosteroids observed in this patient suggests an immunological mechanism [124].

\section{Conclusion}

Neurological manifestations in gluten sensitivity can be categorized into central and peripheral nervous system presentations. The most common central nervous system manifestations include cerebellar syndromes, seizures, and dementias. On the other hand, the peripheral nervous system involvement includes different types of peripheral neuropathies and muscular involvement. These presentations are uncommon in children but this prevalence in adult patients is as many as $36 \%$ [125].GFD is recommended for the patients with clinically, serologically, and histologically confirmed $\mathrm{CD}$. There is a great controversy about the administration of GFD in the patients with neurological manifestations, without gastrointestinal presentation, and confirmed pathological evidence of $\mathrm{CD}$ in distal duodenal biopsy. There is no robust randomized clinical trial evaluating the longterm effects of GFD in these patients. GFD is recommended in the patients with histologically confirmed $\mathrm{CD}$ as well. For the patients with neurological manifestations, without gastrointestinal manifestations, and confirmed pathological evidence of $\mathrm{CD}$ in distal duodenal biopsy, the issue is much more complex. Small study sample size is the most important obstacle for judging about the presence or absence of "gluten ataxia/neuropathy" entities. Both pros and cons conducted studies on fewer than 100 patients. According to our review, it is reasonable that immunological screening should be conducted for the patients with headache, ataxia, and epilepsy, but not MS. 


\section{Acknowledgements}

Research Improvement Center of Shiraz University of Medical Sciences, Shiraz, Iran and Ms. A. Keivanshekouh are appreciated for im- proving the use of English in the manuscript. The authors would like to thank the scientific writing group of student research committee, Shiraz University of Medical Sciences.

\section{References}

1. Di Sabatino A, Corazza GR. Coeliac disease. Lancet. 2009;373(9673):1480-93.

2. Green PH, Cellier C. Celiac disease. N Engl J Med. 2007;357(17):1731-43.

3. Ludvigsson JF, Leffler DA, Bai JC, Biagi F, Fasano A, Green PH, et al. The Oslo definitions for coeliac disease and related terms. Gut. 2013;62:43-52.

4. Malekzadeh R, Sachdev A, Fahid Ali A. Coeliac disease in developing countries: Middle East, India and North Africa. Best Pract Res Clin Gastroenterol. 2005;19(3):351-8.

5. Megiorni F, Mora B, Bonamico M, Barbato M, Nenna R, Maiella G, et al. HLA-DQ and risk gradient for celiac disease. Hum Immunol. 2009;70(1):55-9.

6. Malekzadeh R, Akbari MR. Prevalence of gluten-sensitive enteropathy and coeliac disease in Iran. Eur J Gastroenterol Hepatol. 2007;19(9):825-6.

7. 2001. RoawgotUEGWiA. When is a coeliac a coeliac? Eur J Gastroenterol Hepatol. 2001;13:1123-8.

8. Wahaba PJ, Crusiusc JB, Meijerb WR, Mulder CJ. Gluten challenge in borderline gluten-sensitive enteropathy. The American Journal of Gastroenterology. 2001;96(5):1464-9.

9. Hopper AD, Hadjivassiliou M, Butt S, Sanders DS. Adult coeliac disease. BMJ. 2007;335(7619):558-62.

10. Katz KD, Rashtak S, Lahr BD, Melton J, Krause PK, Maggi K, et al. Screening for celiac disease in a North American population: sequential serology and gastrointestinal symptoms. Am J Gastroenterology. 2011;106:1333-9.

11. Freeman HJ. Risk factors in familial forms of celiac disease. World J Gastroenterol. 2010;16:1828-31.

12. Newnham ED. Does gluten cause gastrointestinal symptoms in subjects without coeliac disease? J Gastroenterol Hepatol. 2011;26(3):132-4.

13. Biesiekierski JR, Newnham ED, Irving PM, Barrett JS, Haines M, Doecke JD, et al. Gluten causes gastrointestinal symptoms in subjects without celiac disease: a double-blind randomized placebo-controlled trial. Am J Gastroenterol. 2011;106:508-14.

14. Cascella NG, Kryszak D, Bhatti B, Gregory P, Kelly DL, Mc Evoy JP, et al. Prevalence of celiac disease and gluten sensitivity in the United States clinical antipsychotic trials of intervention effectiveness study population. Schizophr Bull. 2011;37:94-100.

15. Brown WC. Sprue and Its Treatment. London: Bale and Danielsson; 1908.

16. Elders C. Tropical sprue and pernicious anaemia, aetiology and treatment. . Lancet. 1925;1:75-7.

17. Cooke WT, Smith WT. Neurological disorders associated with adult coeliac disease. Brain. 1966;89(4):683-722.

18. Robinson K. Wernicke's encephalopathy. Emerg Nurse. 2003;11(5):30-3.

19. Marks J, Shuster S, Watson AJ. Smallbowel changes in dermatitis herpetiformis. Lancet. 1966;2(7476):1280-2.

20. Wills AJ, Turner B, Lock RJ, Johnston SL, Unsworth DJ, Fry L. Dermatitis herpetiformis and neurological dysfunction. J Neurol Neurosurg Psychiatry. 2002;72(2):259-61.

21. Finelli PF, McEntee WJ, Ambler M, Kestenbaum D. Adult celiac disease presenting as cerebellar syndrome. Neurology. 1980;30(3):245-9.

22. Banerji NK, Hurwitz LJ. Neurological manifestations in adult steatorrhoea (probable Gluten enteropathy). J Neurol 
Sci. 1971;14(2):125-41.

23. Luostarinen L, Pirttila T, Collin P. Coeliac disease presenting with neurological disorders. Eur Neurol. 1999;42(3):132-5.

24. Pengiran Tengah DS, Wills AJ, Holmes GK. Neurological complications of coeliac disease. Postgrad Med J. 2002;78(921):393-8.

25. Volta U, De Giorgio R, Petrolini N, Stangbellini V, Barbara G, Granito A, et al. Clinical findings and antineuronal antibodies in coeliac disease with neurological disorders. Scand J Gastroenterol. 2002;37(11):1276-81.

26. Vaknin A, Eliakim R, Ackerman Z, Steiner I. Neurological abnormalities associated with celiac disease. J Neurol. 2004;251(11):1393-7.

27. Zelnik N, Pacht A, Obeid R, Lerner A. Range of neurologic disorders in patients with celiac disease. Pediatrics. 2004;113(6):1672-6.

28. Briani C, Samaroo D, Alaedini A. Celiac disease: from gluten to autoimmunity. Autoimmun Rev. 2008;7(8):644-50.

29. Hadjivassiliou M, Grunewald RA, Davies-Jones GA. Gluten sensitivity as a neurological illness. J Neurol Neurosurg Psychiatry. 2002;72(5):560-3.

30. Bushara KO. Neurologic presentation of celiac disease. Gastroenterology. 2005;128(1):92-7.

31. Lionetti E, Francavilla R, Pavone P, Pavone L, Francavilla T, Pulvirenti A, et al. The neurology of coeliac disease in childhood: what is the evidence? A systematic review and meta-analysis. Developmental Medicine and Childhood Neurology. 2010;52:700-7.

32. Hadjivassiliou M, Grunewald RA, Chattopadhyay AK, Davies-Jones GA, Gibson A, Jarratt JA, et al. Clinical, radiological, neurophysiological, and neuropathological characteristics of gluten ataxia. Lancet. 1998;352(9140):1582-5.

33. Bhatia KP, Brown P, Gregory R, Lennox GG, Manji H, Thompson PD, et al. Progressive myoclonic ataxia associated with coeliac disease. The myoclonus is of cortical origin, but the pathology is in the cerebellum. Brain. 1995;118 ( Pt 5):108793.

34. Shams PN, Waldman A, Dogan A,
MacKenzie JM, Plant GT. Ataxia in the setting of complicated enteropathy: double jeopardy. J Neurol Neurosurg Psychiatry. 2002;72(4):527-9.

35. Hadjivassiliou M, Maki M, Sanders DS, Williamson CA, Grunewald RA, Woodroofe NM, et al. Autoantibody targeting of brain and intestinal transglutaminase in gluten ataxia. Neurology. 2006;66(3):373-7.

36. Hadjivassiliou M, Grunewald RA, Lawden M, Davies-Jones GA, Powell T, Smith CM. Headache and CNS white matter abnormalities associated with gluten sensitivity. Neurology. 2001;56(3):385-8.

37. Alaedini A, Green PH, Sander HW, Hays AP, Gamboa ET, Fasano A, et al. Ganglioside reactive antibodies in the neuropathy associated with celiac disease. J Neuroimmunol. 2002;127(1-2):145-8.

38. Chin RL, Sander HW, Brannagan TH, Green PH, Hays AP, Alaedini A, et al. Celiac neuropathy. Neurology. 2003;60(10):1581-5.

39. Luostarinen L, Himanen SL, Luostarinen M, Collin P, Pirttila T. Neuromuscular and sensory disturbances in patients with well treated coeliac disease. J Neurol Neurosurg Psychiatry. 2003;74(4):490-4.

40. Silano M, Vincentini O, Luciani A, Felli C, Caserta S, Esposito S, et al. Early tissue transglutaminase-mediated response underlies K562(S)-cell gliadin-dependent agglutination. Pediatr Res. 2012;71:532-8.

41. Hadjivassiliou M, Boscolo S, DaviesJones GA, Grunewald RA, Not T, Sanders $\mathrm{DS}$, et al. The humoral response in the pathogenesis of gluten ataxia. Neurology. 2002;58(8):1221-6.

42. Lauriere M, Bouchez I, Doyen C, Eynard L. Identification of glycosylated forms of wheat storage proteins using twodimensional electrophoresis and blotting. Electrophoresis. 1996;17(3):497-501.

43. Alaedini A, Okamoto H, Briani C, Wollenberg K, Shill HA, Bushara KO, et al. Immune cross-reactivity in celiac disease: anti-gliadin antibodies bind to neuronal synapsin I. J Immunol. 2007;178(10):6590-5.

44. Kaida K, Ariga T, Yu RK. Antiganglioside antibodies and their pathophysiological effects on Guillain-Barre syndrome and 
related disorders-a review. Glycobiology. 2009;19(7):676-92.

45. Sollid LM, Molberg O, McAdam S, Lundin KE. Autoantibodies in coeliac disease: tissue transglutaminase--guilt by association? Gut. 1997;41(6):851-2.

46. Hadjivassiliou M, Grunewald R, Sharrack B, Sanders D, Lobo A, Williamson C, et al. Gluten ataxia in perspective: epidemiology, genetic susceptibility and clinical characteristics. Brain. 2003;126(3):685-91.

47. Deconinck N, Scaillon M, Segers V, Groswasser JJ, Dan B. Opsoclonusmyoclonus associated with celiac disease. Pediatr Neurol. 2006;34(4):312-4.

48. Green PH, Alaedini A, Sander HW, Brannagan TH, Latov N, Chin RL. Mechanisms underlying celiac disease and its neurologic manifestations. Cell Mol Life Sci. 2005;62(7-8):791-9.

49. Shill HA, Alaedini A, Bushara KO, Latov N, Hallett M. Anti-ganglioside antibodies in idiopathic and hereditary cerebellar degeneration. Neurology. 2003;60(10):1672-3.

50. Almaguer-Mederos LE, Almira YR, Gongora EM, Gotay DA, Zaldivar YG, Pupo RE, et al. Antigliadin antibodies in Cuban patients with spinocerebellar ataxia type 2. J Neurol Neurosurg Psychiatry. 2008;79(3):315-7.

51. Ihara M, Makino F, Sawada H, Mezaki T, Mizutani K, Nakase H, et al. Gluten sensitivity in Japanese patients with adult-onset cerebellar ataxia. Intern Med. 2006;45(3):135-40.

52. Hadjivassiliou M, Sanders DS, Grunewald RA, Woodroofe N, Boscolo S, Aeschlimann D. Gluten sensitivity: from gut to brain. Lancet Neurol. 2010;9(3):31830.

53. Combarros O, Infante J, Lopez-Hoyos M, Bartolome MJ, Berciano J, Corral J, et al. Celiac disease and idiopathic cerebellar ataxia. Neurology. 2000;54(12):2346.

54. Lock RJ, Pengiran Tengah DS, Unsworth DJ, Ward JJ, Wills AJ. Ataxia, peripheral neuropathy, and anti-gliadin antibody. Guilt by association? J Neurol Neurosurg Psychiatry. 2005;76(11):1601-3.

55. Wong D, Dwinnel M, Schulzer M, Nimmo M, Leavitt BR, Spacey SD. Ataxia and the role of antigliadin antibodies. Can J Neurol
Sci. 2007;34(2):193-6.

56. Gobbi G, Ambrosetto P, Zaniboni MG, Lambertini A, Ambrosioni G, Tassinari CA. Celiac disease, posterior cerebral calcifications and epilepsy. Brain Dev. 1992;14(1):23-9.

57. Pfaender M, D'Souza WJ, Trost N, Litewka L, Paine M, Cook M. Visual disturbances representing occipital lobe epilepsy in patients with cerebral calcifications and coeliac disease: a case series. J Neurol Neurosurg Psychiatry. 2004;75(11):1623-5.

58. Pengiran Tengah CD, Lock RJ, Unsworth DJ, Wills AJ. Multiple sclerosis and occult gluten sensitivity. Neurology. 2004;62(12):2326-7.

59. Hadjivassiliou M, Sanders DS, Grunewald RA. Multiple sclerosis and occult gluten sensitivity. Neurology. 2005;64(5):933-4.

60. Borhani Haghighi A, Ansari N, Mokhtari M, Geramizadeh B, Lankarani KB. Multiple sclerosis and gluten sensitivity. Clin Neurol Neurosurg. 2007;109(8):6513.

61. Nicoletti A, Patti F, Lo Fermo S, Sciacca A, Laisa P, Liberto A, et al. Frequency of celiac disease is not increased among multiple sclerosis patients. Mult Scler. 2008;14(5):698-700.

62. Shor DB, Barzilai O, Ram M, Izhaky D, Porat-Katz BS, Chapman J, et al. Gluten sensitivity in multiple sclerosis: experimental myth or clinical truth? Ann N Y Acad Sci. 2009;1173:343-9.

63. Bergamaschi R, Jarius S, Robotti M, Pichiecchio A, Wildemann B, Meola G. Two cases of benign neuromyelitis optica in patients with celiac disease. J Neurol. 2009;256(12):2097-9.

64. Jarius S, Jacob S, Waters P, Jacob A, Littleton E, Vincent A. Neuromyelitis optica in patients with gluten sensitivity associated with antibodies to aquaporin-4. J Neurol Neurosurg Psychiatry. 2008;79(9):1084.

65. Alehan F, Ozcay F, Erol I, Canan O, Cemil T. Increased risk for coeliac disease in paediatric patients with migraine. Cephalalgia. 2008;28(9):945-9.

66. Gabrielli M, Cremonini F, Fiore G, Addolorato G, Padalino C, Candelli M, et al. Association between migraine and 
Celiac disease: results from a preliminary case-control and therapeutic study. Am J Gastroenterol. 2003;98(3):625-9.

67. Lionetti E, Francavilla R, Maiuri L, Ruggieri M, Spina M, Pavone P, et al. Headache in pediatric patients with celiac disease and its prevalence as a diagnostic clue. J Pediatr Gastroenterol Nutr. 2009;49(2):202-7.

68. Roche Herrero MC, Arcas Martinez J, Martinez-Bermejo A, Lopez Martin V, Polanco I, Tendero Gormaz A, et al. [The prevalence of headache in a population of patients with coeliac disease]. Rev Neurol. 2001;32(4):301-9.

69. Cicarelli G, Della Rocca G, Amboni M, Ciacci C, Mazzacca G, Filla A, et al. Clinical and neurological abnormalities in adult celiac disease. Neurol Sci. 2003;24(5):311-7.

70. Spina M, Incorpora G, Trigilia $T$, Branciforte F, Franco G, Di Gregorio F. Headache as atypical presentation of celiac disease: report of a clinical case. Pediatr Med Chir. 2001;23:133-5.

71. Hu WT, Murray JA, Greenaway MC, Parisi JE, Josephs KA. Cognitive impairment and celiac disease. Arch Neurol. 2006;63(10):1440-6.

72. Lurie Y, Landau DA, Pfeffer J, Oren R. Celiac disease diagnosed in the elderly. $\mathrm{J}$ Clin Gastroenterol. 2008;42(1):59-61.

73. Frisoni GB, Carabellese N, Longhi M, Geroldi C, Bianchetti A, Govoni S, et al. Is celiac disease associated with Alzheimer's disease? Acta Neurol Scand. 1997;95(3):147-51.

74. Hallert C, Astrom J. Intellectual ability of adults after lifelong intestinal malabsorption due to coeliac disease. J Neurol Neurosurg Psychiatry. 1983;46(1):87-9.

75. Burk K, Farecki ML, Lamprecht G, Roth G, Decker P, Weller M, et al. Neurological symptoms in patients with biopsy proven celiac disease. Mov Disord. 2009;24(16):2358-62.

76. Hallert C, Derefeldt T. Psychic disturbances in adult coeliac disease.

I. Clinical observations. Scand J Gastroenterol. 1982;17(1):17-9.

77. Pavone L, Fiumara A, Bottaro G, Mazzone D, Coleman M. Autism and celiac disease: failure to validate the hypothesis that a link might exist. Biol Psychiatry. 1997;42(1):72-5.

78. West J, Logan RF, Hubbard RB, Card TR. Risk of schizophrenia in people with coeliac disease, ulcerative colitis and Crohn's disease: a general populationbased study. Aliment Pharmacol Ther. 2006;23(1):71-4.

79. Batista IC, Gandolfi L, Nobrega YK, Almeida RC, Almeida LM, Junior DC, et al. Autism spectrum disorder and celiac disease: no evidence for a link. Arq Neuropsiquiatr. 2012;70:28-33.

80. Millward C, Ferriter M, Calver S, ConnellJones G. Gluten- and casein-free diets for autistic spectrum disorder. Cochrane Database Syst Rev. 2004;(2).

81. Buie T, Campbell DB, Fuchs GJ, Furuta GT, Levy J, VandeWater J, et al. Evaluation, diagnosis, and treatment of gastrointestinal disorders in individuals with ASDs: a consensus report. Pediatrics. 2010;125(1):1-18.

82. Ibrahim SH, Voigt RG, Katusic SK, Weaver AL, Barbaresi WJ. Incidence of gastrointestinal symptoms in children with autism: A population-based study. Pediatrics. 2009;124:680-6.

83. Hall DA, Parsons J, Benke T. Paroxysmal nonkinesigenic dystonia and celiac disease. Mov Disord. 2007;22(5):708-10.

84. Nanji AA, Freeman HJ, Anderson FH. Paralysis and rhabdomyolysis: a presenting feature of celiac disease. West J Med. 1982;136(3):273-4.

85. Kitiyakara T, Jackson M, Gorard DA. Refractory coeliac disease, small-bowel lymphoma and chorea. J R Soc Med. 2002;95(3):133-4.

86. Pereira AC, Edwards MJ, Buttery PC, Hawkes CH, Quinn NP, Giovannoni G, et al. Choreic syndrome and coeliac disease: a hitherto unrecognised association. Mov Disord. 2004;19(4):478-82.

87. Leggio L, Cadoni G, D’Angelo C, Mirijello A, Scipione S, Ferrulli A, et al. Coeliac disease and hearing loss: preliminary data on a new possible association. Scand J Gastroenterol. 2007;42(10):1209-13.

88. Volta U, Ferri GG, De Giorgio R, Fabbri A, Parisi C, Sciajno L, et al. Sensorineural 
hearing loss and celiac disease: a coincidental finding. Can J Gastroenterol. 2009;23(8):531-5.

89. Goodwin FC, Beattie RM, Millar J, Kirkham FJ. Celiac disease and childhood stroke. Pediatr Neurol. 2004;31(2):139-42.

90. Audia S, Duchene C, Samson M, Muller G, Bielefeld P, Ricolfi F, et al. Stroke in young adults with celiac disease. Rev Med Interne. 2008;29(3):228-31.

91. Di Lazzaro V, Pilato F, Batocchi AP, Restuccia D, Cammarota G, Profice P. Tired legs--a gut diagnosis. Lancet. 2010;376(9754):1798.

92. Goodman BP, Mistry DH, Pasha SF, Bosch PE. Copper deficiency myeloneuropathy due to occult celiac disease. Neurologist. 2009;15(6):355-6.

93. Murinson BB. Stiff-Person Syndrome. Neurologist. 2004;10 (3):131-7.

94. Kelkar P, Ross MA, Murray J. Mononeuropathy multiplex associated with celiac sprue. Muscle Nerve. 1996;19(2):234-6.

95. Brannagan TH, Hays AP, Chin SS, Sander HW, Chin RL, Magda P, et al. Small-fiber neuropathy/neuronopathy associated with celiac disease: skin biopsy findings. Arch Neurol. 2005;62(10):1574-8.

96. Ludvigsson JF, Olsson T, Ekbom A, Montgomery SM. A population-based study of coeliac disease, neurodegenerative and neuroinflammatory diseases. Aliment Pharmacol Ther. 2007;25(11):1317-27.

97. Hadjivassiliou M, Grunewald RA, Kandler RH, Chattopadhyay AK, Jarratt JA, Sanders DS, et al. Neuropathy associated with gluten sensitivity. J Neurol Neurosurg Psychiatry. 2006;77(11):1262-6.

98. Selva-O'Callaghan A, Casellas F, de Torres I, Palou E, Grau-Junyent JM, VilardellTarres M. Celiac disease and antibodies associated with celiac disease in patients with inflammatory myopathy. Muscle Nerve. 2007;35(1):49-54.

99. Hadjivassiliou M, Chattopadhyay AK, Grunewald RA, Jarratt JA, Kandler RH, Rao DG, et al. Myopathy associated with gluten sensitivity. Muscle Nerve. 2007;35(4):443-50.

100. Alawneh K, Ashley C, Carlson JA. Neutrophilic myositis as a manifestation of celiac disease: a case report. Clin
Rheumatol. 2008;27(1):11-3.

101. Marie I, Lecomte F, Hachulla E, Antonietti M, Francois A, Levesque H, et al. An uncommon association: celiac disease and dermatomyositis in adults. Clin Exp Rheumatol. 2001;19(2):201-3.

102.Hadjivassiliou M, Chattopadhyay AK, Davies-Jones GA, Gibson A, Grunewald RA, Lobo AJ. Neuromuscular disorder as a presenting feature of coeliac disease. J Neurol Neurosurg Psychiatry. 1997;63(6):770-5.

103.Burk K, Bosch S, Muller CA, Melms A, Zuhlke C, Stern M, et al. Sporadic cerebellar ataxia associated with gluten sensitivity. Brain. 2001;124(5):1013-9.

104.Pellecchia MT, Scala R, Filla A, De Michele G, Ciacci C, Barone P. Idiopathic cerebellar ataxia associated with celiac disease: lack of distinctive neurological features. J Neurol Neurosurg Psychiatry. 1999;66(1):32-5.

105.Hadjivassiliou M, Gibson A, Davies-Jones GA, Lobo AJ, Stephenson TJ, MilfordWard A. Does cryptic gluten sensitivity play a part in neurological illness? Lancet. 1996;347(8998):369-71.

106. Hadjivassiliou M, Aeschlimann P, Strigun A, Sanders DS, Woodroofe N, Aeschlimann D. Autoantibodies in gluten ataxia recognize a novel neuronal transglutaminase. Ann Neurol. 2008;64(3):332-43.

107. Bushara KO, Nance M, Gomez CM. Antigliadin antibodies in Huntington's disease. Neurology. 2004;62(1):132-3.

108. Ghezzi A, Filippi M, Falini A, Zaffaroni M. Cerebral involvement in celiac disease: a serial MRI study in a patient with brainstem and cerebellar symptoms. Neurology. 1997;49(5):1447-50.

109. Siqueira Neto JI, Costa AC, Magalhaes FG, Silva GS. Neurological manifestations of celiac disease. Arq Neuropsiquiatr. 2004;62(4):969-72.

110.Chinnery PF, Reading PJ, Milne D, Gardner-Medwin D, Turnbull DM. CSF antigliadin antibodies and the Ramsay Hunt syndrome. Neurology. 1997;49(4):1131-3.

111.Muller AF, Donnelly MT, Smith CM, Grundman MJ, Holmes GK, Toghill PJ. Neurological complications of celiac 
disease: a rare but continuing problem. Am

J Gastroenterol. 1996;91(7):1430-5.

112. Hadjivassiliou M, Kandler RH,

Chattopadhyay AK, Davies-Jones AG, Jarratt JA, Sanders DS, et al. Dietary treatment of gluten neuropathy. Muscle Nerve. 2006;34(6):762-6.

113. Molteni N, Bardella MT, Baldassarri AR,

Bianchi PA. Celiac disease associated with epilepsy and intracranial calcifications: report of two patients. Am J Gastroenterol. 1988;83(9):992-4.

114. Hernandez MA, Colina G, Ortigosa L. Epilepsy, cerebral calcifications and clinical or subclinical coeliac disease. Course and follow up with gluten-free diet. Seizure. 1998;7(1):49-54.

115. Canales P, Mery VP, Larrondo FJ, Bravo FL, Godoy J. Epilepsy and celiac disease: favorable outcome with a gluten-free diet in a patient refractory to antiepileptic drugs. Neurologist. 2006;12(6):318-21.

116. Pratesi R, Modelli IC, Martins RC, Almeida PL, Gandolfi L. Celiac disease and epilepsy: favorable outcome in a child with difficult to control seizures. Acta Neurol Scand. 2003;108:290-3.

117. Addolorato G, Stefanini GF, Capristo E, Caputo F, Gasbarrini A, Gasbarrini G. Anxiety and depression in adult untreated celiac subjects and in patients affected by inflammatory bowel disease: a personality "trait" or a reactive illness? Hepatogastroenterology. 1996;43(12):1513-7.

118. Brown KJ, Jewells V, Herfarth H, Castillo M. White Matter Lesions Suggestive of Amyotrophic Lateral Sclerosis Attributed to Celiac Disease. AJNR Am J Neuroradiol. 2010;31(5):880-1.
119. Russell JA. Osteomalacic myopathy. Muscle Nerve. 1994;17(6):578-80.

120. Ward ME, Murphy JT, Greenberg GR. Celiac disease and spinocerebellar degeneration with normal vitamin E status. Neurology. 1985;35(8):1199-201.

121. Souayah N, Chin RL, Brannagan TH, Latov N, Green PH, Kokoszka A, et al. Effect of intravenous immunoglobulin on cerebellar ataxia and neuropathic pain associated with celiac disease. Eur J Neurol. 2008;15(12):1300-3.

122. Nanri K, Otsuka T, Takeguchi M, Taguchi T, Ishiko T, Mitoma H, et al. A case of anti-gliadin-antibody-positive cerebellar ataxia effectively treated with intravenous immunoglobulin in which voxelbased morphometry and FineSRT were diagnostically useful. Rinsho Shinkeigaku. 2009;49(1):37-42.

123.Nanri K, Okita M, Takeguchi M, Taguchi T, Ishiko T, Saito H, et al. Intravenous immunoglobulin therapy for autoantibodypositive cerebellar ataxia. Intern Med. 2009;48(10):783-90.

124. Ait Ben Haddou E, Errabih I, Raissouni L, Elhassani M, Benomar A, Ouazzani $\mathrm{H}$, et al. Interest of corticosteroids in neurological complications of celiac disease. Rev Neurol (Paris). 2009;165(12):1103-6.

125. Chaudhry V, Ravich WJ. Other neurological disorders associated with gastrointestinal, liver, or pancreatic diseases. Neurology and General Medicine. 3th ed. . Churchill Livingston. 2001:283-4. 